\title{
Impact of Chitosan, Trichoderma harzianum, Thyme Oil and Jojoba Extract against Fusarium Wilt Disease of Strawberry
}

\author{
Magdy A. Massoud*, A. M. Kordy*, A. A. Abdel-Mageed*, A. I. A. Heflish* \\ and M. M. Sehier* \\ *Plant Protection Department, Faculty of Agriculture (Saba-Basha), Alex. Univ. \\ ${ }^{\star *}$ Agricultural Botany Department, Faculty of Agriculture (Saba-Basha), Alex. Univ.
}

\begin{abstract}
The impact of chitosan, Trichoderma harzianum, thyme oil and jojoba extract against $F$. oxysporum, wilt disease of strawberry, was studied in laboratory and throughout the following growing seasons of (2018 and 2019) in greenhouse. The antagonistic biocontrol agent, Trichoderma harzianum, was isolated and identified in lab at the Faculty of agriculture Saba Basha, Alexandria, Egypt. In laboratory tests, the effect of the tested biocontrol agents on fungal mean growth in vivo was determined. In the greenhouse experiments, the treatments were performed in three application methods: foliar, soil drench and the mixed foliar/soil method. In lab tests, Chitosan ${ }^{\circledR}(4 \mathrm{~g} / \mathrm{l})$ followed by $T$. harzianum and Top perfect ${ }^{\Theta}(4 \mathrm{ml} / \mathrm{l})$ reduced the fungal growth of Fusarium oxysporum pathogen by $86.3,85.9 \%$ and $78.2 \%$, respectively. In green house experiments, the data showed that the mixed application treatment (soil drench and foliar spray) is important for controlling Fusarium oxysporum pathogen. Thyme oil was less effective than the other treatments as biocontrol agent for the pathogen. The Highest determined chlorophyll content was determined in the treatment of $T$. harzianum (48.23), Chitosan $\AA$ (47.66) and Top perfect $\AA$ (44.97), without significant differences between $T$. harzianum and chitosan, especially in the mixed application treatment. Moreover, the treatments of Chitosan ${ }^{\circledR}, T$. harzianum and Top perfect ${ }^{\circledR}$, significantly, showed the highest fresh, dry weights and root length of plants and the least disease incidence and severity percentages compared with the untreated control.
\end{abstract}

\section{INTRODUCTION}

Strawberries are individuals from the family Rosaceae, subfamily Rosoideae, and genus Fragaria (Hummer \& Janick, 2009). Strawberries are cultivated in a wide climatic levels, although they are most successfully grown in Mediterranean and temperate climates, which their temperatures ranging between 15 and $30^{\circ} \mathrm{C}$ in the summer season and between 15 and $20^{\circ} \mathrm{C}$ in the winter season(Guerrero-Chavez, Scampicchio, \& Andreotti, 2015). The sweet strawberry, $F$. ananassa, now dominates strawberry production in nearly all arable regions of the world. Annual strawberry production has increased steadily during most of the $20^{\text {th }}$ century with a slight increase in the rate of growth over the past few decades. The last 20 years have seen production more than double from 3.5 million tons in 1993 to over 8.5 million tons in 2013 (FAOSTAT, 2014). Egypt total area harvested 8880 ha in 2018, in addition to the total of production of strawberries 362639 ton in 2018 (FAOSTAT, 2018). Strawberry is susceptible to numerous soil-borne diseases including root rot, red stele, fusarium wilt, and verticillium wilt. In addition, strawberry is affected by several plant parasitic nematodes. Several diseases of strawberry are caused by pathogen complexes. For instance, root rot disease is caused by a consortium consisting of Fusarium spp and Rhizoctonia fragariae in association with $P$. penetrans (Particka \& Hancock, 2005). Root rot disease produced by many pathogens, as Fusarium oxysporum, Macrophomina phaseolina, Pythium spp. and Rhizoctonia spp. (Fang, Finnegan, \& Barbetti, 2013). The disease symptom is root death, decline and make black of the main root, and a decay in potency and yield of the plant and significant decrease in the production (Fang, You, \& Barbetti, 2012) F. oxysporum causes many soil borne diseases as root 
and crown rot and wilt disease (Menzies \& Jarvis, 1994). These diseases caused high losses of yield amount and quality (Ruiz-Romero, Valdez-Salas, González-Mendoza, \& Mendez-Trujillo, 2018). The bioagent Trichoderma harzianum achieved a markable inhibition of the plant pathogen, Fusarium oxysporum, under in vitro condition (Krishna, Nataraj, Rajeshwari, Kirtimala, \& Nagaraj, 2019). Thyme (Thymus vulgaris) essential oil (TEO) and its ingredients could be used as environmentally friendly biofungicides in the protection of wheat plants against Fusarium species (Faghih-Imani, Taheri, \& Tarighi, 2020). Chitosan is well-known as bio-control agent because of its nontoxic, biodegradable and biocompatible properties against pathogenic microorganisms by preventing their growth and sporulation (Hassan \& Chang, 2017). Now environmental pollution produced by application of chemicals and the random effects of biological control have been commonly evaluated(Zargar et al., 2017). Although pesticides, sometime reaches significant effects, however its effects induced damage of the environment and there organisms. Therefore, the target of this work is to replace the chemical fungicides by other safe approaches as bio-control, which is could be more effective and safe approach.

\section{MATERIALS AND METHODS}

\section{The tested biocontrol agents:}

Chitosan $^{\circledR}$ : The deacetylated chitin (chitosan) derived from the exoskeleton of shell of crustacean such as shrimp, lobster, crab, squilla, krill, etc., has high economic value owing to its versatile biological activities and agrochemical applications (Badawy et al., 2005). Chitosan is active against viruses, bacteria, fungi, nematodes, and other pests when applied as a foliar or soil treatment, It activated the defense system of the host plant and prevented the invasion of pathogens(El Hadrami, Adam, El Hadrami, \& Daayf, 2010). The tested chitosan was a powder form produced by Roth, Germany.

Top perfect ${ }^{\circledR} 60 \%$ Ec: The formulation contains Jojoba seeds extraction. Jojoba oil, used to control mildew, Jojoba oil is the liquid produced in the seed of the Simmondsia chinensis (Jojoba) plant. The oil is structurally different from triglycerides, which are what most of the other seed oils are made of. It has a high shelf life and can be stored for long periods as it is a relatively stable liquid. It does not oxidize easily and will not turn rancid compared to other oils because it does not contain triglycerides (Nimir \& Ali-Dinar, 1989). The botanical product was supplied from Top Chemical Company.

Thyme oil: Thyme can refer to plants from the genus Thymus, which is in the family Labiatae, along with the genera Rosmarinus, Lavendula and Salvia. The most widely used species, Thymus vulgaris, is known as common or garden thyme (Morales, 2002). Most thyme oil is produced by steam distillation of the flowering tops of T. vulgaris or T. zygis (Khan \& Abourashed, 2011). Thyme oil is rich in the phenolic compound thymol, which is believed to be the main biologically active component (Zarzuelo \& Crespo, 2002). Thyme oil was purchased as pure oil from Prof. Dr. Salama EL-Darier, Prof of Plant Ecology and Herbal Medicine, Department of Botany and Microbiology, Faculty of Science, Alexandria University, Egypt. 
Trichoderma harzianum: The use of Trichoderma species as biological control agents has been investigated for over 70 years but it is only relatively recently that strains have become available commercially. Most isolates of the genus Trichoderma that were found to act as mycoparasites of many economically important aerial and soil-borne plant pathogens, have been classified as $T$. harzianum (Gams \& Meyer, 1998). The species "harzianum" is generally considered as a group made of mycoparasitic and biocontrol strains. The antagonistic potential is the base for effective applications of different Trichoderma strains as an alternative to the chemical control against a wide set of fungal plant pathogens (Harman, 1998).

A. Laboratory tests: Four biocontrol agents namely Chitosan ${ }^{\circledR}$, Top perfect ${ }^{\circledR}$, thyme oil and Trichoderma harzianum were evaluated against the plant pathogen, Fusarium oxysporum under laboratory conditions. Three concentrations were tested for each of Chitosan ${ }^{\circledR}$, Top perfect ${ }^{\circledR}$, thyme oil (Table, 1).

Table (1). Materials and their concentration that used in the laboratory studies

\begin{tabular}{cc}
\hline Biocontrol agent & Concentration \\
\hline Chitosan $^{\circledR}$ powder & $1.0,2.0$ and $4.0 \mathrm{~g} / \mathrm{L}$ \\
Top perfect $^{\oplus} 60 \% \mathrm{Ec}$ & $1.0,2.0$ and $4.0 \mathrm{ml} / \mathrm{L}$ \\
Thyme oil $_{\text {Trichoderma harzianum }}$ & $1.0,2.0$ and $4.0 \mathrm{ml} / \mathrm{L}$ \\
& $1 \times 10^{7}$ spore $/ \mathrm{ml}$ \\
\hline
\end{tabular}

\section{Isolation of the pathogen:}

Samples of infected strawberry plants were taken from Abo-elkhaw village, Komhamada, El-Beheira Governorate, Egypt. The roots were rinsed, and dried by air, the samples were sterilized in 1\% sodium hypo chloride surface sterilized for three minutes, rinsed by sterilized distilled water many times and put it between 2 sterilized filter papers to make dried. The sterilized samples were moved to plates containing potato Dextrose agar medium (PDA). Petri-dishes were incubated at $25^{\circ} \mathrm{C}$ for 3 days. The progress of hyphal growth was picked up and moved onto new Petri-dishes. Purification of the isolated fungus was carried out using the hyphal tip technique followed by (Hawker, 1956) . Identification of the isolated fungus was approved by their cultural and morphological characteristics defined by (Barnett \& Hunter, 1987). Then, the stock cultures was kept on PDA slants and saved in the refrigerator at $5^{\circ} \mathrm{C}$.

\section{Isolation of the antagonistic microorganisms:}

Healthy roots of strawberry were collected from strawberry field. Their rhizospheric soils were utilized for collecting many antagonistic microorganisms by the technique defined by (Ahmed, 2005). One gram of rhizospheric soil was put into $99 \mathrm{ml}$ sterilized water; shacked 15 minutes and serial dilutions up to $10^{-}$ ${ }^{4}$ were prepared. Autoclaved potato dextrose agar + rose Bengal + streptomycin medium (Johnson, Curl, Bond, \& Fribourg, 1959) was used for isolating the antagonistic fungi. One $\mathrm{ml}$ of each dilution was aseptically transferred to sterilized Petri-dishes; containing $10 \mathrm{ml}$ of melted warm agar medium and three plates were used for each dilution. All plates were incubated at $25 \pm 1^{\circ} \mathrm{C}$ for 4 
days. Identification of the isolated fungus was approved followed by their cultural and morphological characteristics defined by(Schleifer, 2009). Identification was confirmed at the Faculty of agriculture Saba Basha, Alexandria, Egypt.

\section{Evaluation of Trichoderma harzianum as a biocontrol agent against Fusarium oxysporum by the dual culture technique}

The antagonistic isolate of Trichoderma harzianum was evaluated against $F$. oxysporum by dual culture technique as described by Dennis and Webster (1971). Five $\mathrm{mm}$ diameter mycelial discs of the Trichoderma culture and $F$. oxysporum were placed opposite to each other in the petri plates at equal distance from the periphery. The antagonists were inoculated at one side of petri dish containing PDA. Discs from the culture of $F$. oxysporum were placed at the opposite side of petri dishes perpendicular to the antagonists and incubated at $28^{\circ} \mathrm{C}$. Petri dishes inoculated with fungal pathogen discs alone served as control. Three replications were maintained for each isolate. Radial growth of $F$. oxysporum isolates was recorded and inhibition percent of pathogen growth was calculated by using the following formula:

$$
\text { Inhibition }(\%)=\frac{C-T}{C} \times 100
$$

Where, C- mycelial growth of pathogen in control

T- mycelial growth of pathogen in dual culture plate

\section{Evaluation of chitosan, thyme oil and formulation of jojoba oil as biofungicide against $F$. oxysporum}

Chitosan solution was prepared by dissolving the chitosan in $0.1 \mathrm{~N}$ acetic acid and diluted in distilled water with $\mathrm{pH}$ adjusted at 6.5. Chitosan solution were prepared at three diverse concentrations 0.0, 1.0, 2.0 and $4.0 \mathrm{~g} / \mathrm{L}$ followed by (Benhamou \& Bélanger, 1998). Thyme oil was added at 0.0, 1.0\%, $2.0 \%$, and $4.0 \%(\mathrm{v} / \mathrm{v})$ concentration. Top perfect (jojoba oil) was used at concentrations of $0.0,1.0,2.0$ and $4.0 \mathrm{ml} / \mathrm{L}$. Each treatment concentration was put into warm sterilized PDA medium and was shacked before transferred into Petri dishes (10 ml/plate) mycelial disks $(5 \mathrm{~mm}$ in diameter) from the (Fusarium oxysporum) were placed in the center of $90-\mathrm{mm}$ Petri dishes containing $10 \mathrm{~mL}$ PDA. Control Plates contained media only. Then were used 3 plates for each treatment. Incubated the Petri-dishes was at $25 \pm 1^{\circ} \mathrm{C}$. Radial growth of $F$. oxysporum isolates was recorded and per cent inhibition of pathogen growth was calculated by using the formula.

$$
\text { Inhibition }(\%)=\frac{C-T}{C} \times 100
$$

Where, C- mycelial growth of pathogen in control

T- mycelial growth of pathogen in dual culture plate

\section{B. Greenhouse experiments:}

Treatments and experimental design Completely randomized design was followed in the experiment with three replications. Experiment conducted under greenhouse conditions at Fac. of Agriculture saba basha, Alexandria University in two season 2018-2019. Plastic pots $20 \mathrm{~cm}$ diameter were sterilized by dipping in $5 \%$ formalin solution for $5 \mathrm{~min}$ and then left to dry. Disinfected sand soil (with $5 \%$ formalin) was distributed in plastic pots. Each pot was injected with 
$10 \mathrm{ml}$ of Fusarium culture suspension $\left(10^{7}\right.$ conidia/ml) (El-Khallal, 2007). Soil infestation was performed 7 days before planting strawberry. Festival cultivar of strawberry transplants acquired from Horticulture Institute, ARC, Giza. Transplants were transplanted in the potted infested or non-infested (control) soil at the level of one transplant per pot and each replicate contained three plants in three pots. pots were kept under greenhouse conditions. Strawberry plants were examined periodically (every week for seven weeks). Percentages of dead plants show root rot symptom were recorded to determine virulence of the pathogen. Treatments were organized in a completely randomized design. Prepared chitosan solution by dissolving the chitosan in $0.1 \mathrm{~N}$ acetic acid and diluted in distilled water with $\mathrm{pH}$ adjusted at 6.5. Chitosan solution was prepared at $4.0 \mathrm{~g} / \mathrm{L}$ concentrations (Benhamou \& Bélanger, 1998), Essential oil, i.e., thyme at concentration of $0.4 \%(\mathrm{v} / \mathrm{v})$, Top perfect (jojobaoil) was used at concentration of $4.0 \mathrm{ml} / \mathrm{L}$, Trichoderma harzianum was used at concentration of $\left(10^{7} \mathrm{spore} / \mathrm{ml}\right)$. Each treatment and a control were evaluated. Every treatments were applied as soil drench, foliar spry and mixing (soil drench and foliar spry). In each treatment data were recorded as root length, chlorophyll index, fresh weight, dry weight, disease incidence percentage and Disease severity percentage.

Disease assessments: In greenhouse experiment, percentage of disease incidence of root rot diseases were determined (49 days from transplanting) post transplanting according to the method described by (Ahmed, 2005) as following :-

$$
\text { Disease incidence } \%=\frac{\text { Number of infected planta }}{\text { Total number of plants }} \times 100
$$

Disease severity (DS) was recorded at the end of experiment according to original scale developed to evaluate disease according to (Ahmed, 2005) as follows: $0=$ no symptoms, $1=1-10 \%$ plants yellowing; $2=1-25 \%$ plants yellowing; $3=26-50 \%$ wilting and yellowing; $4=51-100 \%$ dead plants.

$$
\text { Disease severity } \%=\frac{\sum(\text { disease grade } \times \text { number of plants in each grade })}{\text { Total number of plants } \times \text { highest disease grade }} \times 100
$$

Fresh and dry weights of the plants were assessed separately for shoot and root system according to the analytical procedure developed by (Ostrowska, Gawliński, \& Szczubiałka, 1991). The intensity of the green color of the leaves was measured with the use of a SPAD tool, used for determination of intensity of green color of the leaves (highly correlated with chlorophyll content in the leaves)(Ahmed, 2005).

Statistical analysis: The data were elaborated statistically by ANOVA and significance of the differences between the treatments were evaluated by Student-Newman- Keuls multiple range tests at $p=0.05$.

\section{RESULTS AND DISCUSSION}

\section{Isolation and identification of Fusarium pathogen}

Identification of the isolated fungal cultures from El-Beheira governorate followed according to cultural and morphological characteristics. The isolates were identified as Fusarium oxysporum. Identification was carried out at 
Laboratory of Plant Pathology, Fac. of Agriculture (Saba-Basha), Alexandria University, Egypt.

\section{Effect of the treatments on fungal growth in vivo}

This experiment aimed to evaluate the antagonistic effect of the studied treatments on controlling Fusarium oxysporum pathogen, in addition to select the suitable treatments for in vivo experiments. Results presented in Table, 2 and illustrated in Figure 1 and 2 showed that all evaluated treatments significantly reduced hyphal growth rates of fusarium. However, they significantly varied in their antagonistic potentials. The highest mean values of growth reduction were recorded by Chitosan $^{\circledR}$ at concentration $4 \mathrm{~g} / \mathrm{l}(86.3 \%)$, followed by $T$. harzianum $(85.9 \%)$ and Top perfect ${ }^{\circledR}$ at concentration $4 \mathrm{ml} / \mathrm{l}(78.2$ $\%)$, However, the lowest antagonistic effect against the tested isolate was obtained by thyme oil at concentration $4 \mathrm{ml} / \mathrm{l}(13.3 \%)$.

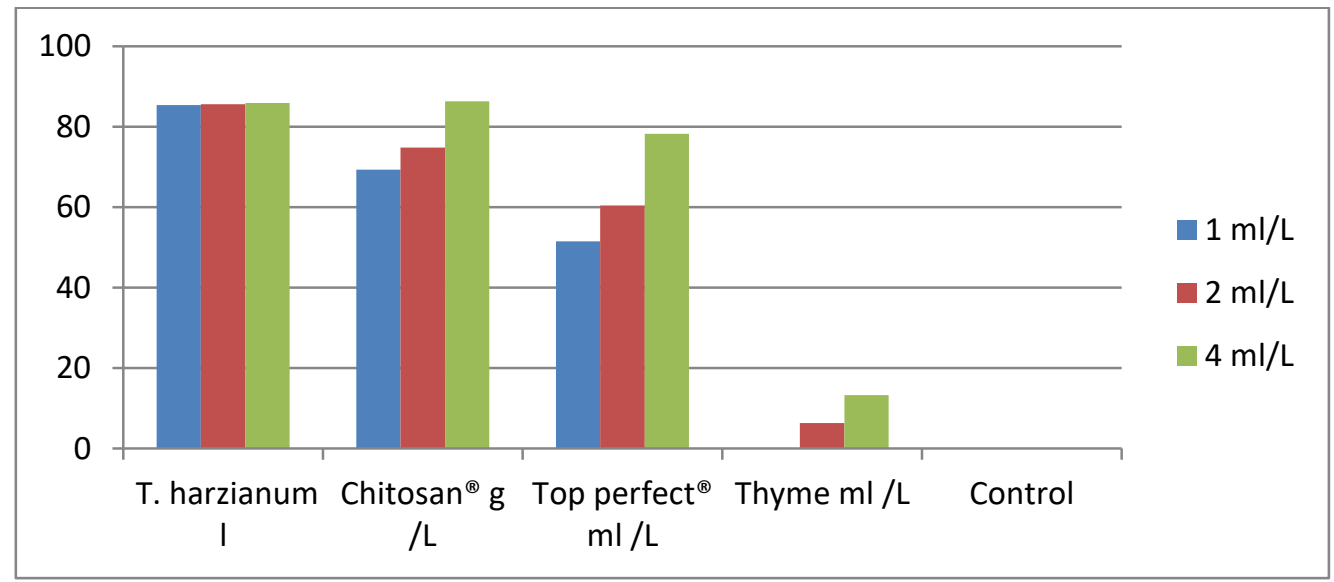

Figure (1). Efficacy of each treatment on fungal growth in vitro

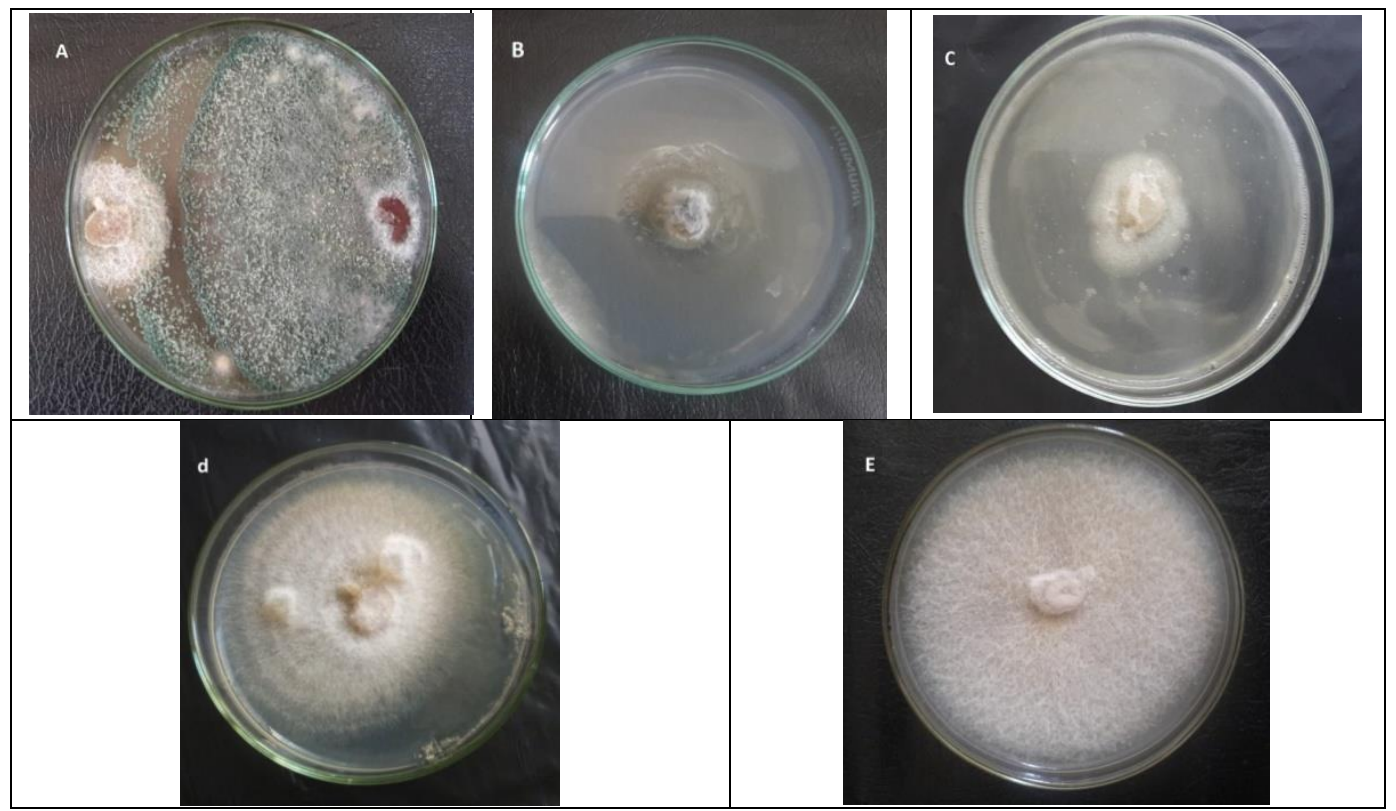

Figure (2). Antagonistic effect of the four tested bio-control agents on Fusarium oxysporum. Where: $\mathrm{A}=T$. harzianum, $\mathrm{B}=$ Chitosan, $\mathrm{C}=$ Top perfect, $\mathrm{D}=$ thyme oil, $\mathrm{E}=$ untreated control 
Table (2). Efficacy of each treatment on F. oxysporum growth in vitro

\begin{tabular}{|c|c|c|c|c|}
\hline \multirow[t]{2}{*}{ Treatments } & \multicolumn{3}{|c|}{$\begin{array}{c}\text { Reduction } \% \\
\text { Concentrations g/l }\end{array}$} & \multirow[t]{2}{*}{ General average } \\
\hline & 1 & 2 & 4 & \\
\hline T. harzianum & $85.4 \mathrm{a}$ & $85.6 \mathrm{a}$ & $85.9 a$ & $85.6 \mathrm{a}$ \\
\hline Chitosan ${ }^{\circledR}$ g /L & $69.3 d$ & $74.8 \mathrm{c}$ & $86.3 \mathrm{a}$ & $76.8 \mathrm{~b}$ \\
\hline Top perfect ${ }^{\circledR} \mathrm{ml} / \mathrm{L}$ & $51.5 \mathrm{hi}$ & $60.4 \mathrm{fg}$ & $78.2 \mathrm{~b}$ & $63.3 \mathrm{~d}$ \\
\hline Thyme $\mathrm{ml} / \mathrm{L}$ & $0.0 \mathrm{~m}$ & 6.31 & $13.3 \mathrm{k}$ & $6.5 \mathrm{~h}$ \\
\hline Control & $0.0 \mathrm{~m}$ & $0.0 \mathrm{~m}$ & $0.0 \mathrm{~m}$ & $0.0 \mathrm{i}$ \\
\hline General average & $44.1 \mathrm{c}$ & $52.4 \mathrm{~b}$ & $59.8 \mathrm{a}$ & \\
\hline
\end{tabular}

Effect of the treatments on fusarium disease under greenhouse conditions

\section{During the first season 2018:}

The results presented in table 3 and Fig. 3 show the efficacy of different treatments against $F$. oxysporum. Every treatment was applied as soil application (soil drench) and as foliar spry. Data were recorded after 7 weeks of transplanting to describe the effect of treatments on the F. oxysporum. whereas, the treatments may be effect on the plant components like that the chlorophyll. $T$. harzianum was the highest effective treatment concerning to chlorophyll for soil drench and mix between soil and foliar sprays application (45.77 and 48.23). In addition, the obtained data cleared that no significant difference between both of $T$. harzianum or Chitosan $\AA$ (47.66) and Top perfect $\circledast$ (41.6) after mixed application. By comparing the effect of three methods of application the highest mean effect on the chlorophyll accrued by the mixed application (42.41) followed by injection method (39.33) and foliar spray (35.93), respectively.

Table (3). Efficiency of the treatments on chlorophyll index during season 2018

\begin{tabular}{|c|c|c|c|c|}
\hline \multirow{3}{*}{ Treatments } & \multicolumn{3}{|c|}{ Chlorophyll index } & \multirow{3}{*}{$\begin{array}{c}\text { Genera } \\
\text { average }\end{array}$} \\
\hline & \multicolumn{3}{|c|}{ Type of application methods } & \\
\hline & Spray & Soil & Mix & \\
\hline T. harzianum & 43.13 efgh & 45.77 bcde & $48.23 \mathrm{a}$ & $45.71 \mathrm{a}$ \\
\hline Chitosan ${ }^{\circledR}$ g / L & $41.83 \mathrm{~h}$ & $45.3 \mathrm{bcdefg}$ & $47.66 \mathrm{ab}$ & $44.93 \mathrm{a}$ \\
\hline Top perfect ${ }^{\circledR} \mathrm{ml} / \mathrm{L}$ & $36.86 \mathrm{i}$ & $43.03 \mathrm{fgh}$ & 44.97 cdefg & $41.62 b$ \\
\hline Thyme $\mathrm{ml} / \mathrm{L}$ & $19.3 \mathrm{k}$ & $35.4 i^{\circ}$ & $37.47 i$ & $30.72 \mathrm{c}$ \\
\hline Control & $19.6 \mathrm{k}$ & $19.56 \mathrm{k}$ & $19.36 \mathrm{k}$ & $19.51 d$ \\
\hline General average & $35.93 \mathrm{c}$ & $39.33 \mathrm{~b}$ & 42.41a & \\
\hline
\end{tabular}

LSD0.05 for Treatments $=0.94$ LSD0.05 for application methods $=0.54$ 


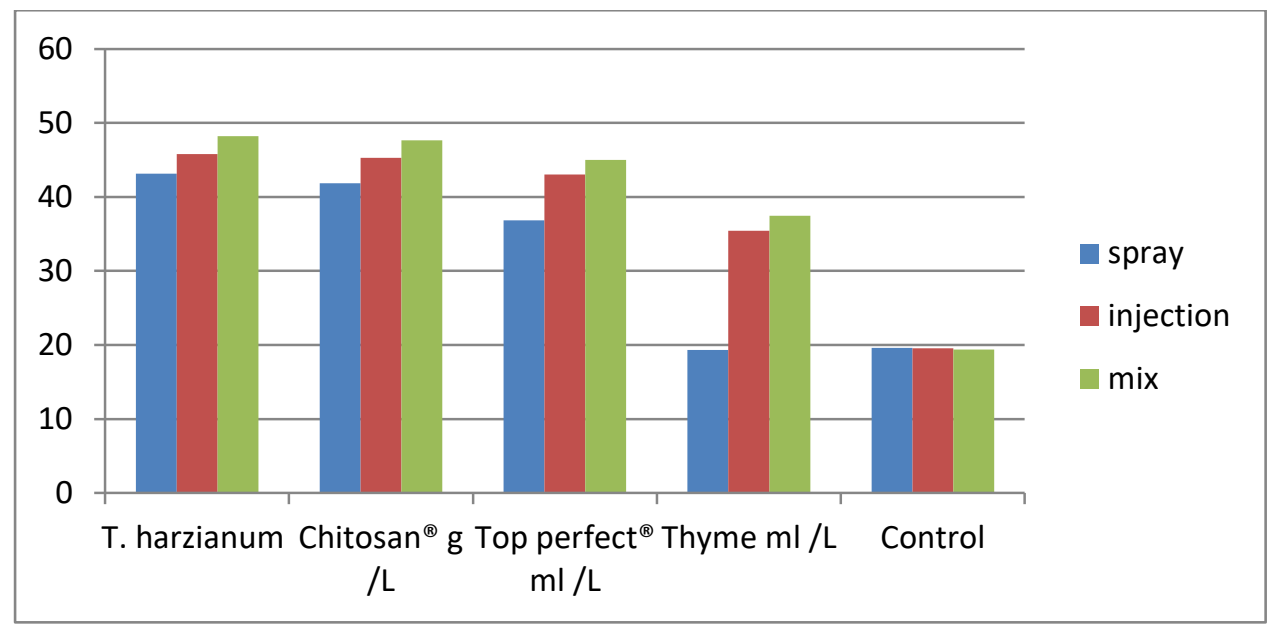

Figure (3). Efficiency of the treatments on chlorophyll index during season 2018

Data presented in table 4 and Fig 4 and 5 indicate that all tested compounds significantly increased fresh and dry weight of plants in the first growing seasons. The highest fresh weight mean achieved by chitosan as mixed treatment (34 gm) followed by $T$. harzianum (30.1gm). The highest mean number accrued by mix application 6.7 a followed by injection (5.2gm) and spray application $(3.8 \mathrm{gm})$, respectively. In addition, chitosan recorded the highest mean weight of the dry weight by the mixed application $(8.6 \mathrm{gm})$ followed by $T$. harzianum $(8.1 \mathrm{gm})$, respectively.

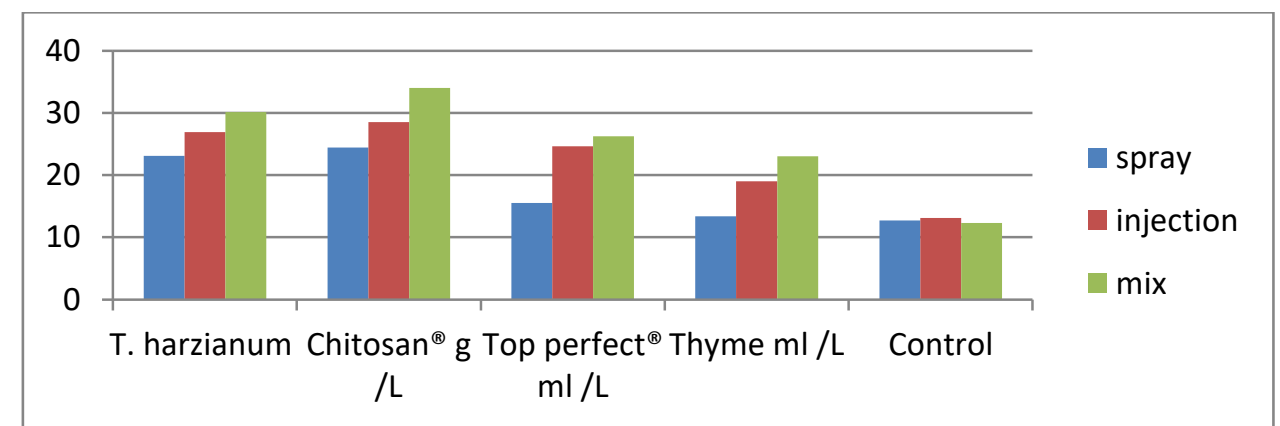

Figure (4). Efficiency of tested biocontrol agents on Strawberry plants (fresh weight) infested by F. oxysporum during season 2018

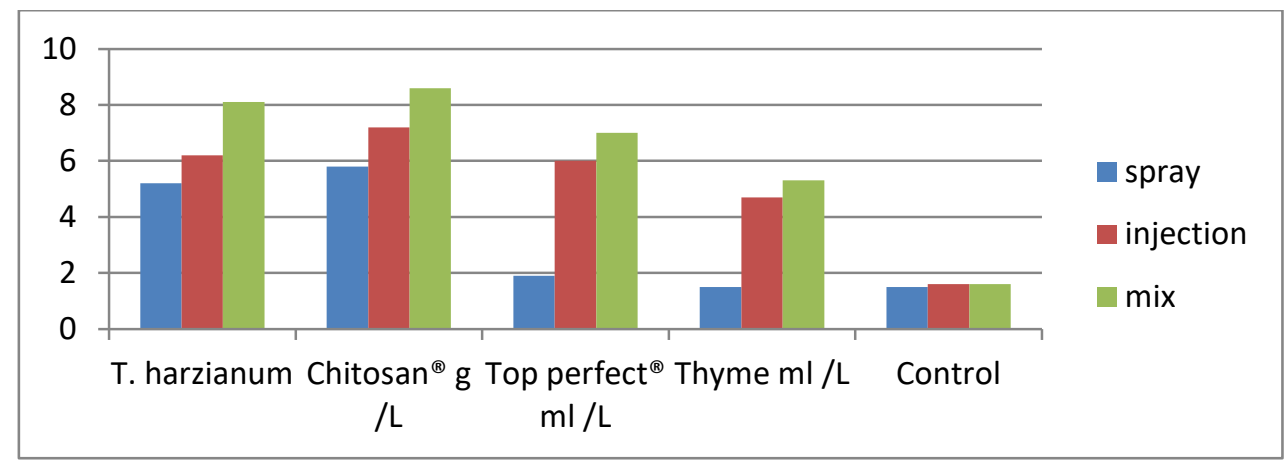

Figure (5). Efficiency of tested biocontrol agents on Strawberry plants (dry weight) infested by $F$. oxysporum during season 2018 
Table (4). Efficiency of tested biocontrol agents on Strawberry fresh and dry weight infeced by Fusarium oxysporum during season 2018

\begin{tabular}{|c|c|c|c|c|c|c|c|c|}
\hline \multirow{3}{*}{ Treatments } & \multirow{2}{*}{\multicolumn{3}{|c|}{$\begin{array}{c}\text { Fresh weight }(\mathbf{g}) \\
\text { Type of application } \\
\text { methods }\end{array}$}} & \multirow{3}{*}{$\begin{array}{l}\text { General } \\
\text { average }\end{array}$} & \multirow{2}{*}{\multicolumn{3}{|c|}{$\begin{array}{c}\text { Dry weight }(\mathbf{g}) \\
\text { Type of application } \\
\text { methods }\end{array}$}} & \multirow{3}{*}{$\begin{array}{l}\text { General } \\
\text { average }\end{array}$} \\
\hline & & & & & & & & \\
\hline & Spray & soil & Mix & & Spray & soil & Mix & \\
\hline T. harzianum & $23.1 \mathrm{ef}$ & $26.9 \mathrm{~cd}$ & $30.1 b$ & $26.8 b$ & 5.2hijk & 6.2 defg & $8.1 a b$ & $6.5 b$ \\
\hline Chitosan ${ }^{\circledR}$ g / L & $24.4 \mathrm{de}$ & $28.5 c$ & $34 \mathrm{a}$ & $29 a$ & $5.8 \mathrm{fghi}$ & $7.2 \mathrm{c}$ & $8.6 \mathrm{a}$ & $7.2 \mathrm{a}$ \\
\hline $\begin{array}{c}\text { Top perfect@ } \\
\mathrm{ml} / \mathrm{L}\end{array}$ & $15.5 \mathrm{~h}$ & 24.6de & $\begin{array}{c}26.2 c \\
d\end{array}$ & $22.1 f$ & $1.9 \mathrm{i}$ & $6 \mathrm{fgh}$ & $7 \mathrm{~cd}$ & $5 e$ \\
\hline $\begin{array}{c}\text { Thyme ml /L } \\
\text { Control }\end{array}$ & $\begin{array}{l}\text { 13.4hij } \\
12.7 \mathrm{ij}\end{array}$ & $\begin{array}{c}19 \mathrm{~g} \\
13.1 \mathrm{ij}\end{array}$ & $\begin{array}{l}23 \text { ef } \\
12.31\end{array}$ & $\begin{array}{l}18.4 \mathrm{~g} \\
12.7 \mathrm{~h}\end{array}$ & $\begin{array}{l}1.5 \mathrm{i} \\
1.5 \mathrm{i}\end{array}$ & $\begin{array}{l}4.7 \mathrm{k} \\
1.6 \mathrm{i}\end{array}$ & $\begin{array}{c}\text { 5.3hijk } \\
1.6 \mathrm{i}\end{array}$ & $\begin{array}{l}3.8 \mathrm{f} \\
1.6 \mathrm{~g}\end{array}$ \\
\hline $\begin{array}{l}\text { General } \\
\text { average }\end{array}$ & $19.7 c$ & $22.6 b$ & $26.7 a$ & & $3.8 \mathrm{c}$ & $5.2 \mathrm{~b}$ & $6.7 a$ & \\
\hline $\begin{array}{l}\text { LSD0.05 for Tre } \\
\text { LSD0.05 for app }\end{array}$ & ion $\mathrm{n}$ & Is 0 & & & 0.0 & & $\mathrm{n}$ meth & 0.19 \\
\hline
\end{tabular}

Table (5).Efficiency of the treatments on(disease incidence and severity) the plants infested by Fusarium oxysporum during season 2018

\begin{tabular}{|c|c|c|c|c|c|c|c|c|}
\hline \multirow{3}{*}{ Treatments } & \multirow{2}{*}{\multicolumn{3}{|c|}{$\begin{array}{l}\text { Disease incidence } \% \\
\text { Type of app. methods }\end{array}$}} & \multirow{3}{*}{$\begin{array}{l}\text { General } \\
\text { average }\end{array}$} & \multirow{2}{*}{\multicolumn{3}{|c|}{$\begin{array}{c}\text { Disease severity } \% \\
\text { Type of app. methods }\end{array}$}} & \multirow{3}{*}{$\begin{array}{l}\text { Genera } \\
\text { average }\end{array}$} \\
\hline & & & & & & & & \\
\hline & Spray & soil & Mix & & Spray & soil & Mix & \\
\hline T. harzianum & 29.6ef & 22.2efgh & 11.1hij & $20.97 c$ & $16.7 f$ & $11.1 \mathrm{gh}$ & 8.3hi & $12.1 \mathrm{e}$ \\
\hline \multirow{2}{*}{$\begin{array}{c}\text { Chitosan } \AA \text { g } / L \\
\text { Top perfect }{ }^{\circledR} \\
\text { ml /L }\end{array}$} & 18.5fghi & $11.1 \mathrm{hij}$ & 7.4ij & $12.4 \mathrm{e}$ & $11.1 \mathrm{gh}$ & $6.5 i$ & $2 \mathrm{j}$ & $6.5 f$ \\
\hline & 33.3de & 25.9efg & 18.5fghi & $25.9 \mathrm{~cd}$ & $27.8 \mathrm{e}$ & $13 g$ & $10.2 \mathrm{gh}$ & $17 d$ \\
\hline $\begin{array}{c}\text { Thyme ml /L } \\
\text { Control }\end{array}$ & $\begin{array}{l}100 \mathrm{a} \\
100 \mathrm{a}\end{array}$ & $\begin{array}{c}48.2 \mathrm{bc} \\
100 \mathrm{a}\end{array}$ & $\begin{array}{l}40.7 c d \\
100 a\end{array}$ & $\begin{array}{l}62.96 b \\
100 a\end{array}$ & $\begin{array}{l}100 \mathrm{a} \\
100 \mathrm{a}\end{array}$ & $\begin{array}{l}43.5 c \\
100 a\end{array}$ & $\begin{array}{l}33.3 d \\
100 a\end{array}$ & $\begin{array}{l}58.9 b \\
100 a\end{array}$ \\
\hline $\begin{array}{l}\text { General } \\
\text { average }\end{array}$ & $44 a$ & $32.5 \mathrm{~b}$ & $28.4 \mathrm{c}$ & & $38.9 a$ & $24.5 b$ & $19.4 \mathrm{c}$ & \\
\hline $\begin{array}{l}\text { LSD0.05 for Treat } \\
\text { LSD0.05 for applic }\end{array}$ & $\begin{array}{l}\text { tments } \\
\text { cation n }\end{array}$ & $\mathrm{d} s=2$ & & $\begin{array}{l}\text { LSD0. } \\
\text { LSD0. }\end{array}$ & or app & ion & ad & \\
\hline
\end{tabular}

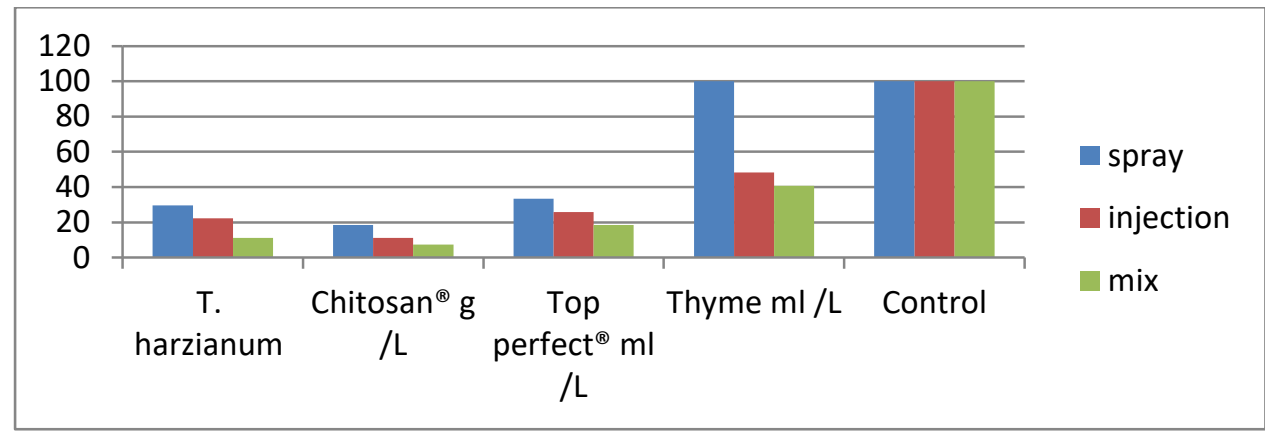

Figure (6). Efficiency of the treatments on disease incidence during season 2018 




Figure (7). Efficiency of the treatments on disease severity during season 2018

\section{Disease incidence (DI \%)}

The obtained results in Table 5 and Fig. 6 showed that all treatments reduced disease incidence and severity significantly in the first seasons. In addition, all application methods achieved high reduction of disease incidence compare with control. The highest reduction disease incidence recoded by chitosan $^{\circledR}$ after mix and soil applications $(7.4 \%$ and $11.1 \%)$ followed by Trichoderma $(20.97 \%)$, top perfect $\circledast$ (25.9\%). Also, when compared between mean number of application methods for disease incidence. Moreover, the highest DI \% value was detected in control mean (100\%), followed by thyme oil mean $(62.96 \%)$. Chitosan ${ }^{\circledR}$ treatment mean achieved the highest reduction of disease incidence (12.4\%).

\section{Disease severity (DS \%)}

According to results presented in Table 5 and Figure 7, variances in DS percentages among the evaluated treatments were, generally, significant. The highest DS\% was achieved on control followed by thyme oil treatment $(100 \%$ and $58.9 \%$ ), sequentially. on the other hand, the most effective treatment of reducing the DS percentages observed by chitosan ${ }^{\circledR}(5.6 \%)$ followed by Trichoderma $(12.7 \%)$ and top perfect ${ }^{\Theta}(17 \%)$. In addition, all application methods achieved high reduction of disease incidence compare with control. The highest reduce effect on disease incidence found by chitosan ${ }^{\circledR}$ after mix and soil application (2\% and 6.5\%). Also, the same trend was observed when compared with mean number of application methods for DS percentages. We found that the highest number for application methods accrued by mix (soil + spray) application (19.4\%).

\section{Effect of biocontrol agents on root length $(\mathrm{cm})$}

The results presented in table 6 and Fig 8 reported that all treatments increased the root length of plants when compared with control. The highest mean number of root length recorded by chitosan $(28.3 \mathrm{~cm})$ followed by $T$. harzianum. When compared with the mean number of treatments the highest mean number of root length occurred by chitosan $(25.6 \mathrm{~cm})$ followed by $T$. harzianum. Nevertheless, when compared with the mean number of application methods the highest mean number occurred after mix application $(24 \mathrm{~cm})$. 
Table (6). effect of tested biocontrol agents on root length of plants infested by Fusarium oxysporum during season 2018

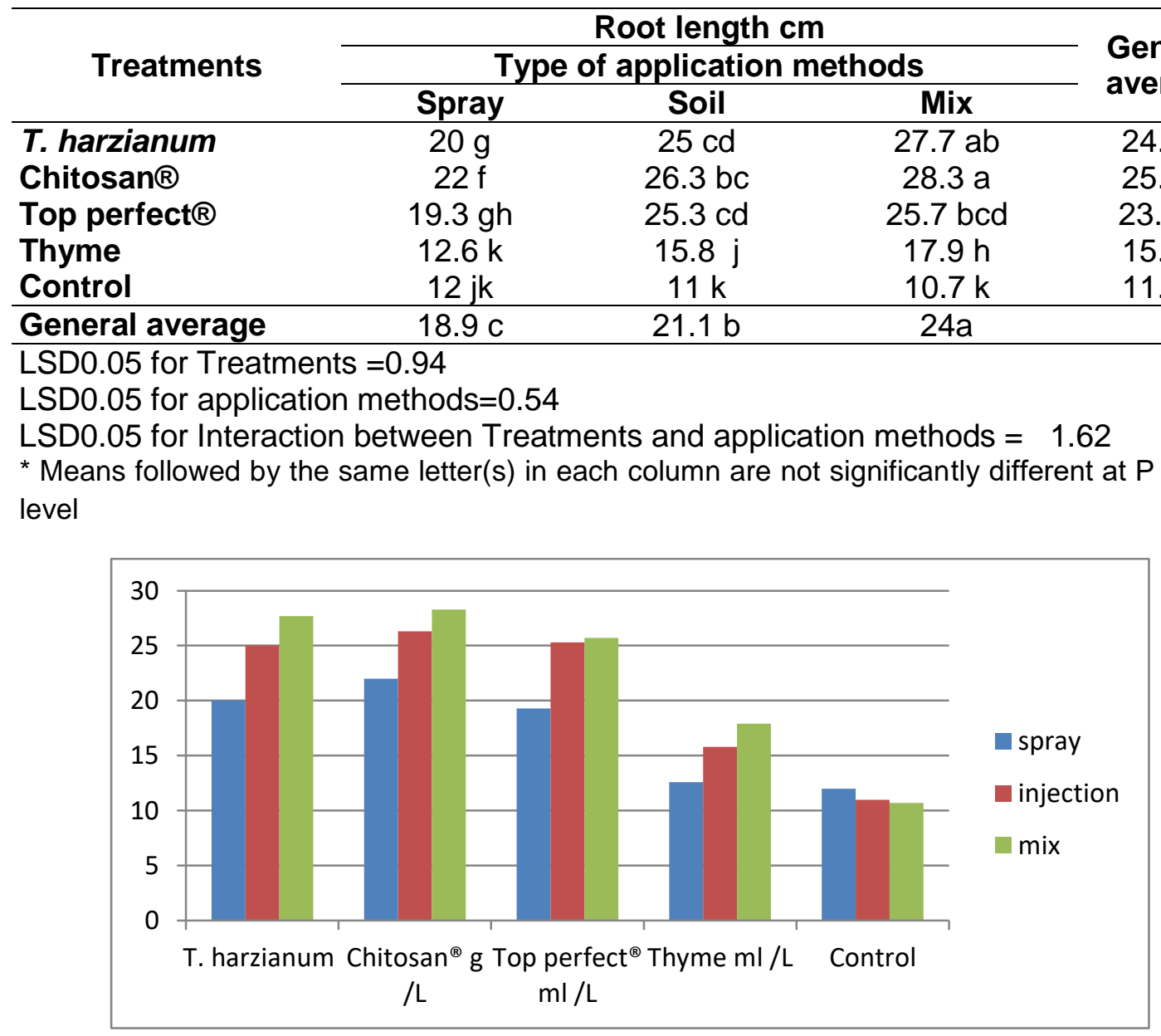

Figure (8). Effect of the treatments on root length during season 2018

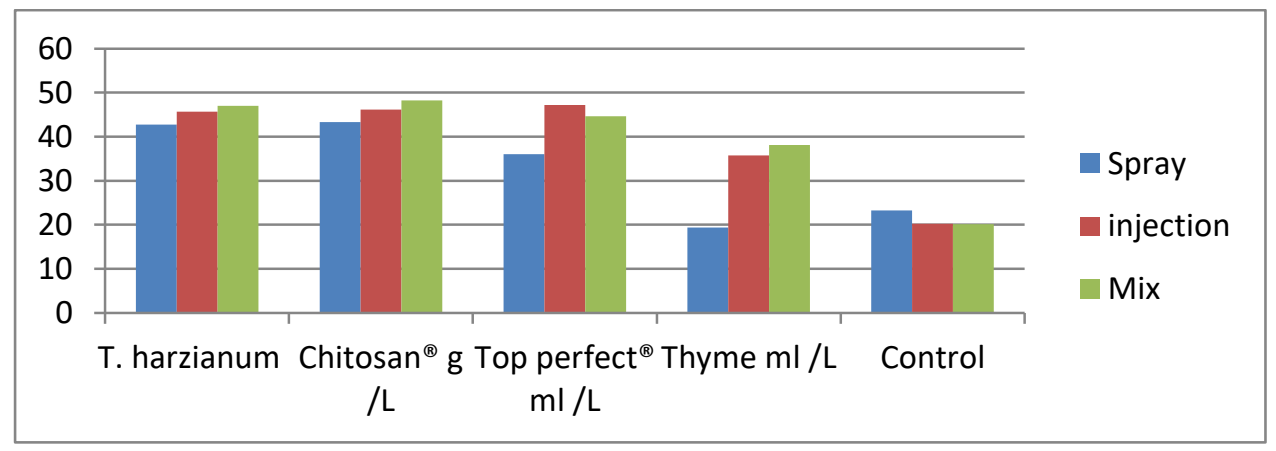

Figure (9). Effect of tested biocontrol agents on chlorophyll index on plants infected by Fusarium oxysporum during season 2019

Data existed in Table 7 and Fig. 9 showed that chitosan ${ }^{\circledR}$ was the highest effective treatment concerning on "chlorophyll for mix application (48.2). In addition, the result were cleared that no significant difference between the chitosan $\AA$ and $T$. harzianum (47) with in the mixed application. The result 
showed that when compared between application methods, the highest effect on the chlorophyll observed by mix application (42.5) followed by soil application method (39.6) and foliar spray (35.1).

Table (7). effect of the treatments on chlorophyll index during season 2019

\begin{tabular}{lcccc}
\hline \multirow{2}{*}{ Treatments } & \multicolumn{3}{c}{ Chlorophyll index } & \multirow{2}{*}{ General } \\
\cline { 2 - 4 } & \multicolumn{2}{c}{ Type of application methods } & average \\
\cline { 2 - 4 } & Spray & Soil & Mix & \\
\hline T. harzianum & $42.7 \mathrm{f}$ & $45.7 \mathrm{bcd}$ & $47 \mathrm{~b}$ & $45.1 \mathrm{ab}$ \\
Chitosan $\AA \mathrm{g} / \mathrm{L}$ & $43.3 \mathrm{ef}$ & $46.1 \mathrm{bc}$ & $48.2 \mathrm{a}$ & $45.9 \mathrm{a}$ \\
Top perfect ${ }^{\circledR} \mathrm{ml} / \mathrm{L}$ & $36 \mathrm{~h}$ & $47.2 \mathrm{ab}$ & $44.6 \mathrm{cde}$ & $41 \mathrm{~d}$ \\
Thyme $\mathbf{~ m l ~} / \mathbf{L}$ & $19.4 \mathrm{k}$ & $35.7 \mathrm{~h}$ & $38.1 \mathrm{~g}$ & $31.1 \mathrm{f}$ \\
Control & $23.2 \mathrm{i}$ & $20.2 \mathrm{jk}$ & $20.1 \mathrm{jk}$ & $21.2 \mathrm{~g}$ \\
\hline General average & $35.1 \mathrm{c}$ & $39.6 \mathrm{~b}$ & $42.5 \mathrm{a}$ & \\
\hline
\end{tabular}

LSD0.05 for Treatments $=0.73$ LSD0.05 for application methods $=0.42$

Data illustrated in Table 8 and Fig 10 and 11 indicated that all tested compounds significantly increased fresh and dry weight of plants. In this regard, the highest efficacy on mean fresh weight achieved by $T$. harzianum and chitosan on mix treatment recorded $(33.9 \mathrm{~g}),(33.5 \mathrm{~g})$, respectively. The highest mean number obtained by mix application (6.3 g) followed by injection (5.3 g) and foliar spry application (3.8 g), respectively. Also, when determined the dry weight after mix application $T$. harzianum recorded the highest mean number $(8.4 \mathrm{~g})$ followed by chitosan® $(7.9 \mathrm{~g})$.

Table (8). Effect of the treatments on fresh and dry weight during season 2019

\begin{tabular}{|c|c|c|c|c|c|c|c|c|}
\hline \multirow{3}{*}{ Treatments } & \multicolumn{3}{|c|}{ Fresh weight (g) } & \multirow{3}{*}{$\begin{array}{l}\text { General } \\
\text { average }\end{array}$} & \multirow{2}{*}{\multicolumn{3}{|c|}{$\begin{array}{c}\text { Dry weight (g) } \\
\text { Type of application } \\
\text { methods }\end{array}$}} & \multirow{3}{*}{$\begin{array}{l}\text { General } \\
\text { average }\end{array}$} \\
\hline & \multicolumn{3}{|c|}{ Type of application methods } & & & & & \\
\hline & Spray & Injection & Mix & & Spray & injection & Mix & \\
\hline \multirow{3}{*}{$\begin{array}{c}\text { T. harzianum } \\
\text { Chitosan }{ }^{\circledR} \\
\text { g/L } \\
\text { Top perfect }{ }^{\circledR} \\
\text { ml /L }\end{array}$} & $23.1 \mathrm{fg}$ & $26.2 \mathrm{cde}$ & $33.9 a$ & $27.7 a$ & 5.1ghi & $6.6 \mathrm{~cd}$ & $8.4 a$ & $6.7 a$ \\
\hline & 24.8def & $28.3 \mathrm{bc}$ & $33.5 a$ & $28.5 a$ & 5.8defg & $6.7 \mathrm{~cd}$ & $7.9 a b$ & $6.8 \mathrm{a}$ \\
\hline & $15.3 i$ & 24.3ef & $27.4 \mathrm{cde}$ & $22.3 d$ & $1.8 \mathrm{j}$ & 6.2 cdef & $6.5 \mathrm{~cd}$ & $4.8 d$ \\
\hline Thyme ml /L & $12.7 \mathrm{j}$ & $18 \mathrm{~h}$ & $23.3 \mathrm{fg}$ & $18 \mathrm{e}$ & $1.5 \mathrm{j}$ & $4.9 \mathrm{ghi}$ & $\begin{array}{l}5.6 \\
\text { defghi }\end{array}$ & 4 e \\
\hline Control & $11.9 \mathrm{j}$ & $12.3 \mathrm{j}$ & $12.6 \mathrm{j}$ & $12.3 f$ & $1.6 \mathrm{j}$ & $1.4 \mathrm{j}$ & $1.4 \mathrm{j}$ & $1.5 \mathrm{f}$ \\
\hline $\begin{array}{l}\text { General } \\
\text { average }\end{array}$ & $18.9 \mathrm{c}$ & $22.7 b$ & 26.9 a & & $3.8 \mathrm{c}$ & $5.3 \mathrm{~b}$ & $6.3 \mathrm{a}$ & \\
\hline $\begin{array}{l}\text { LSD0.05 for } \mathrm{Tr} \\
\text { LSD0.05 for ap }\end{array}$ & atme & $s=0$. & & LSI & & & & \\
\hline
\end{tabular}






Figure (10). Effect of the treatments on fresh weight of plants during season 2019

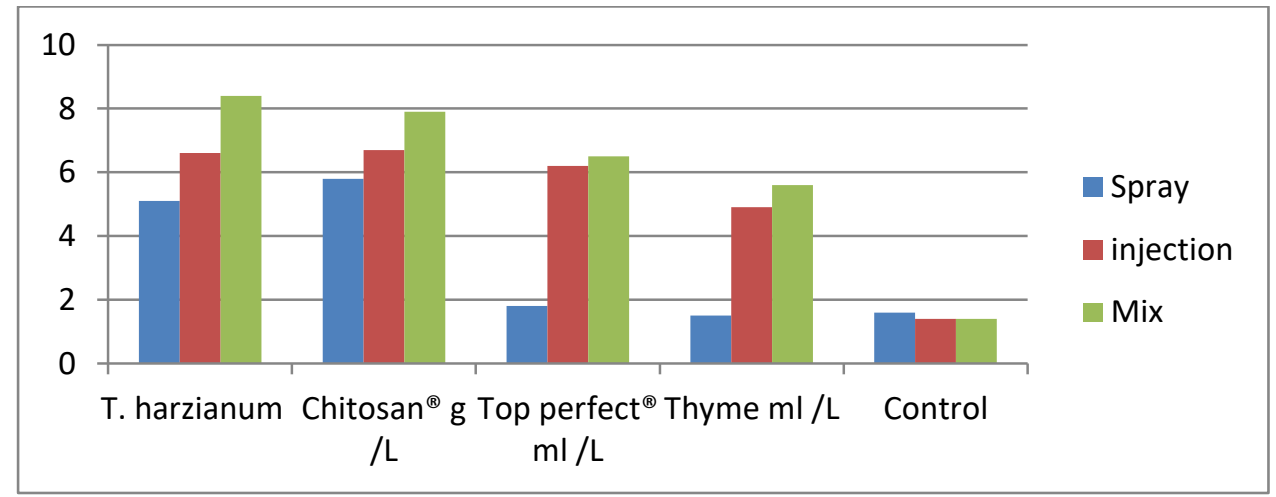

Figure (11). Effect of the treatments on dry weight of plants during season 2019

Table (9). Effect of the treatments on disease incidence and disease severity 2019

\begin{tabular}{|c|c|c|c|c|c|c|c|c|}
\hline \multirow[t]{2}{*}{ Treatments } & \multicolumn{3}{|c|}{\begin{tabular}{|l|} 
Disease incidence \% \\
application methods \\
\end{tabular}} & \multirow{2}{*}{$\begin{array}{l}\text { General } \\
\text { average }\end{array}$} & \multicolumn{3}{|c|}{$\begin{array}{c}\text { Disease severity \% } \\
\text { application methods }\end{array}$} & \multirow{2}{*}{$\begin{array}{l}\text { General } \\
\text { average }\end{array}$} \\
\hline & Spray & soil & Mix & & Spray & soil & Mix & \\
\hline T. harzianum & 22.2defg & 22.2defg & 11.1ghi & $18.5 d$ & $16.7 e$ & $11.1 \mathrm{fg}$ & 7.4hi & $11.7 d$ \\
\hline Chitosan $®$ g /L & 14.8fghi & 11.1ghi & 7.4hi & $11.1 \mathrm{e}$ & $11.1 \mathrm{fg}$ & 7.4hi & $1.9 \mathrm{j}$ & $6.8 e$ \\
\hline $\begin{array}{c}\text { Top perfect@ } \\
\mathrm{ml} / \mathrm{L}\end{array}$ & $33.3 \mathrm{~cd}$ & 25.9def & 25.6de & $29.6 c$ & $33.3 d$ & $13 f$ & $11.1 \mathrm{fg}$ & $19.2 c$ \\
\hline Thyme $\mathrm{ml} / \mathrm{L}$ & $100 a$ & $51.9 b$ & $40.4 c$ & $64.2 b$ & $100 a$ & $43 c$ & $33.3 d$ & $58.6 b$ \\
\hline Control & $100 a$ & $100 a$ & $100 a$ & $100 a$ & $100 a$ & $100 a$ & $100 a$ & $100 a$ \\
\hline $\begin{array}{l}\text { General } \\
\text { average }\end{array}$ & $39.5 a$ & $24.5 b$ & $25.9 c$ & & $39.5 a$ & $24.5 b$ & $19.5 c$ & \\
\hline $\begin{array}{l}\text { LSD0.05 for Tre } \\
\text { and for applicat }\end{array}$ & lethods & & & and for & Trr & no & & \\
\hline
\end{tabular}






Figure (12). Effect of tested biocontrol agents on disease incidence of plants infected by Fusarium oxysporum during season 2019

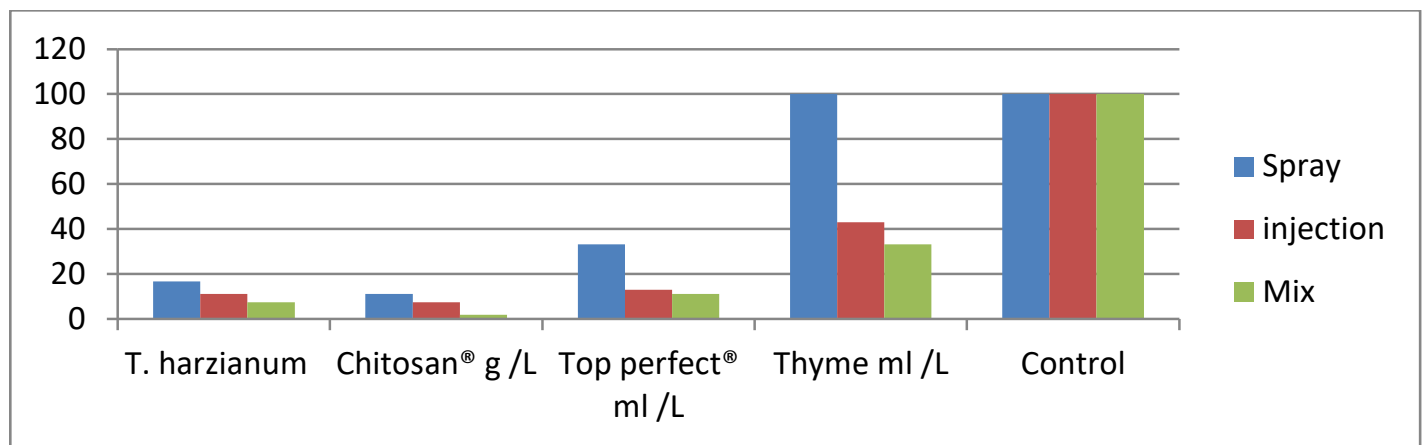

Figure (13). Efficiency of tested biocontrol agents on Strawberries (disease severity) infected by Fusarium oxysporum during season 2019

\section{Disease incidence and disease severity}

The obtained results showed in Table 9 and Fig. 12 and 13 cleared that all treatments significantly reduced disease incidence and severity in both growing seasons. The highest reduce disease incidence accrued by Chitosan ${ }^{\circledR}$ after mix and soil application $(7.4 \%$ and $11.1 \%)$ followed by $T$. harzianum(11.1\%) by mix application. The same result obtained on disease severity by chitosan (1.9\%). Also, the mixed application method showed the most effective in decreasing disease incidence and severity to only $25.9 \%$ and $19.5 \%$, respectively compared with the other application methods.



Figure (14). Effect of tested biocontrol agents on Strawberry (root length) infested by Fusarium oxysporum during season 2019 
Table (10). Effect of tested biocontrol agents on Strawberry (root length) infested by Fusarium oxysporum during season 2019

\begin{tabular}{|c|c|c|c|c|}
\hline \multirow{3}{*}{ Treatments } & \multicolumn{3}{|c|}{ Root length (cm) } & \multirow{3}{*}{$\begin{array}{l}\text { Genera } \\
\text { average }\end{array}$} \\
\hline & \multicolumn{3}{|c|}{ Type of application methods } & \\
\hline & Spray & soil & Mix & \\
\hline T. harzianum & $19.7 \mathrm{fg}$ & $26 \mathrm{bc}$ & $27.7 \mathrm{ab}$ & $24.4 \mathrm{~b}$ \\
\hline Chitosan $® \mathrm{~g} / \mathrm{L}$ & $22.7 \mathrm{e}$ & $26.3 \mathrm{abc}$ & $28.3 \mathrm{a}$ & $25.8 \mathrm{a}$ \\
\hline Top perfect $\AA \mathrm{ml} / \mathrm{L}$ & $19.7 \mathrm{fg}$ & $25 \mathrm{~cd}$ & $26.3 \mathrm{abc}$ & $23.7 \mathrm{bc}$ \\
\hline Thyme $\mathrm{ml} / \mathrm{L}$ & $13.4 i$ & $15.6 \mathrm{~h}$ & $17.8 \mathrm{~g}$ & $15.6 \mathrm{e}$ \\
\hline Control & $13 i$ & $11 \mathrm{j}$ & $12 i j$ & $12 \mathrm{f}$ \\
\hline General average & $18.8 \mathrm{c}$ & $21.6 \mathrm{~b}$ & $24.2 \mathrm{a}$ & \\
\hline
\end{tabular}

During season 2019, the results showed in (Table 10 and Fig. 14) reported that all treatments increased the root length Strawberries when compared with untreated control. The highest mean number of root length recorded by chitosan (28.3\%) followed by $T$. harzianum $(27.7 \%)$. When compared with between the mean number of treatments the highest mean number of root length accrued by chitosan $(25.8 \%)$ followed by $T$. harzianum. However, when compared with the mean number of application methods the highest mean number occurred on mix application (24.2\%)

\section{DISCUSSION}

\section{Effect of the treatments on fungal growth in vitro}

The highest mean values of fungal growth reduction were induced by Chitosan (86.3\%) at concentration $4 \mathrm{~g} / \mathrm{l}$, followed by $T$. harzianum $(85.9 \%)$ and Top perfect ${ }^{\circledR}(78.2 \%)$. However, the lowest antagonistic effect against the tested isolates was obtained by thyme oil (13.3\%). Similar results were mentioned by (Li, Sun, Yang, Ge, \& Yi, 2009) who studied the antifungal activity of chitosan on Fusarium spp. causing dry rot of potato tuber, High reduction of mycelial growth of Fusarium spp. achieved by the application of chitosan at higher concentration causing more damage to fungal hyphae. As well, In vitro treatments of $\mathrm{CH}+\mathrm{SA}$ in PDA medium caused the maximum inhibition in the linear growth and spore germination of $F$. solani incubated plates compared to control plates. Moreover, (Krishna et al., 2019)) evaluated the effect of six bio agents against $F$. oxysporum under in vitro condition. $T$. harzianum was more effective against the pathogen and exhibited $(90.06 \%)$ percent inhibition. In addition, (Redda et al., 2018) evaluated the antagonistic efficacy of Trichoderma spp. against $F$. oxysporum and found strong antagonistic potential which inhibited $>50 \%$ linear growth of $F$. oxysporum. Furthermore, (Suleiman, Gambo, \& Sunusi, 2019) reported that T. harzianum isolates had the highest effect of inhibition the linear growth of the pathogen $F$. oxysporum compared to control in vitro.

\section{Antagonistic effects of evaluated treatments on strawberry root rot disease}

The results proved that all treatments achieved high reduction of disease incidence and severity. In addition the tested treatments increased the chlorophyll index, total fresh weight, dry weight and root length of strawberry 
plants agree with our obtained results (Mukta et al., 2017) studied the efficiency of chitosan and fungicides on strawberry production. Chitosan @ 250-500 ppm was applied on Strawberry Festival achieved 56\% higher production compared to control and Fungicide application. (El-Mohamedy, Shafeek, Abd El-Samad, Salama, \& Rizk, 2017) results indicated that soaking bean seeds in $\mathrm{CH} 1.0 \mathrm{~g} / \mathrm{l}+$ SA $5 \%$ trailed by spray application, caused in the highest inhibition of dampingoff and root rot incidence $70.0 \%$, compared with control. As well (Sinha, Harshita, Singh, \& Verma, 2018) evaluated T. harzianum and T. viride for their efficacy against $F$. oxysporum in green house conditions. T. harzianumhas also achieved the highest germination along with improved plant height, root length and yield. (Khan et al., 2017)Found that T. harzianum achieved $75.5 \%$ inhibition of colony growth of $F$. oxysporum pathogen followed by incubation for $72 \mathrm{~h}$ at $28+2^{\circ} \mathrm{C}$ in vitro. Furthermore the reduction of disease severity on pot experiment. More ever (Moosa et al., 2017) reported that $F$. oxysporum causing wilt disease, affecting huge losses in yield. They evaluated the effects of the antagonistic isolates of $T$. harzianum against $F$. oxysporum. Trichoderma isolates achieved the highest reduction best on Fusarium wilt of tomato. Furthermore (Ahmed \& El-Fiki, 2017) found that Trichoderma spp. The highest growth reduction of tried pathogen $F$. oxysporum was occurred by $T$. harzianum(74.67 mm). Moreover application of Trichoderma spp. achieved high increase in phenols, nitrogen and chlorophyll index. On other hand (Mansour \& El-Sharkawy, 2014) evaluated Jojoba (Simmondsi achinensis) oil activity on Squash root rot disease that caused by $R$. solani and $F$. solani. The results indicated to the reduction of damping- off and dead plant compared with untreated seeds. Squash seeds treated with Jojoba oil increased fruit yield/plot and plant survival compared with control. As well (Baraka, Radwan, Shaban, \& Arafat, 2011) evaluated the efficacy of jojoba as fixed oil at 500 ppm against root rots pathogen of date palm tree caused by $F$. oxysporum and many fungi. The result indicated that jojoba as fixed oil and other essential oils have most reduction of the plant pathogen.

\section{REFERENCES}

Ahmed, M. (2005). Effect of adding some biocontrol agents on non-target microorganisms in root diseases infecting soybean and broad bean plants. M. Sc. Thesis. Faculty of Agriculture Moshtohor, Benha Univ.

Ahmed, M., \& El-Fiki, I. (2017). Effect of biological control of root rot diseases of strawberry using Trichoderma spp. Sciences, 7(03), 482-492.

Badawy, M. E., Rabea, E. I., Rogge, T. M., Stevens, C. V., Steurbaut, W., Höfte, M., \& Smagghe, G. (2005). Fungicidal and insecticidal activity of O-acyl chitosan derivatives. Polymer bulletin, 54(4-5), 279-289.

Baraka, M., Radwan, F. M., Shaban, W., \& Arafat, K. (2011). Efficiency of some plant extracts, natural oils, biofungicides and fungicides against root rot disease of date palm. Journal of Biodiversity and Environmental Sciences, 25.

Barnett, H., \& Hunter, B. (1987). Illustrallated general of imperfecti fungi: Burges Publishing company, Minnesota.

Benhamou, N., \& Bélanger, R. R. (1998). Benzothiadiazole-Mediated Induced Resistance toFusarium oxysporum f. sp. radicis-lycopersici in Tomato. Plant physiology, 118(4), 1203-1212. 
El Hadrami, A., Adam, L. R., El Hadrami, I., \& Daayf, F. (2010). Chitosan in plant protection. Marine drugs, 8(4), 968-987.

El-Khallal, S. M. (2007). Induction and modulation of resistance in tomato plants against Fusarium wilt disease by bioagent fungi (arbuscular mycorrhiza) and/or hormonal elicitors (jasmonic acid \& salicylic acid): 2changes in the antioxidant enzymes, phenolic compounds and pathogen related-proteins. Aust J Basic App/ Sci, 1(4), 717-732.

El-Mohamedy, R. S. R., Shafeek, M. R., Abd El-Samad, E. E.-D. H., Salama, D. M., \& Rizk, F. A. (2017). Field application of plant resistance inducers (PRIs) to control important root rot diseases and improvement growth and yield of green bean (Phaseolus vulgaris L.). Australian Journal of Crop Science, 11(5), 496.

Faghih-Imani, M.-H., Taheri, P., \& Tarighi, S. (2020). Antifungal and Virulence-Modulating Effects of Thyme Essential Oil against Fusarium spp., Causing Wheat Diseases. Applied Microbiology: Theory \& Technology, 22-38.

Fang, X., Finnegan, P. M., \& Barbetti, M. J. (2013). Wide variation in virulence and genetic diversity of binucleate Rhizoctonia isolates associated with root rot of strawberry in Western Australia. PloS one, 8(2).

Fang, X., You, M. P., \& Barbetti, M. J. (2012). Reduced severity and impact of Fusarium wilt on strawberry by manipulation of soil $\mathrm{pH}$, soil organic amendments and crop rotation. European journal of plant pathology, 134(3), 619-629.

FAOSTAT, F. (2014). Food and Agriculture Organization statistical database. Retrieved Feb.

FAOSTAT, F. (2018). Food and Agriculture Organization statistical database. Retrieved Dec.

Gams, W., \& Meyer, W. (1998). What exactly is Trichoderma harzianum? Mycologia, 90(5), 904-915.

Guerrero-Chavez, G., Scampicchio, M., \& Andreotti, C. (2015). Influence of the site altitude on strawberry phenolic composition and quality. 192, 2128.

Harman, G. (1998). Potential and existing uses of Trichoderma and Gliocladium for plant disease control and plant growth enhancement. Trichoderma and gliocladium, 2, 229-265.

Hassan, O., \& Chang, T. (2017). Chitosan for eco-friendly control of plant disease. Asian J Plant Pathol, 11(2), 53-70.

Hawker, R. (1956). Inactivation of antidiuretic hormone and oxytocin during pregnancy. Quarterly Journal of Experimental Physiology and Cognate Medical Sciences: Translation and Integration, 41(3), 301-308.

Hummer, K. E., \& Janick, J. (2009). Rosaceae: taxonomy, economic importance, genomics Genetics and genomics of Rosaceae (pp. 1-17): Springer.

Johnson, L. F., Curl, E. A., Bond, J. H., \& Fribourg, H. A. (1959). Methods for studying soil microflora: plant disease relationships. Retrieved from

Khan, B., Akash, Z., Asad, S., Javed, N., Rajput, N. A., Jabbar, A., . . . Atif, R. M. (2017). Antagonistic Potential of Trichoderma harzianum against Fusarium oxysporum f. sp. cubense associated with Panama Wilt of Banana. Pakistan Journal of Phytopathology, 29(1), 111-116. 
Khan, I. A., \& Abourashed, E. A. (2011). Leung's encyclopedia of common natural ingredients: used in food, drugs and cosmetics: John Wiley \& Sons.

Krishna, G., Nataraj, S., Rajeshwari, R., Kirtimala, B., \& Nagaraj, H. (2019). In vitro Evaluation of Bioagents against Fusarium Wilt of China Aster caused by Fusarium oxysporum f. sp. Callistephi and its effect on Growth Parameters under Pot Condition. Int. J. Curr. Microbiol. App. Sci, 8(10), 1773-1781.

Li, Y.-C., Sun, X.-J., Yang, B., Ge, Y.-H., \& Yi, W. (2009). Antifungal activity of chitosan on Fusarium sulphureum in relation to dry rot of potato tuber. Agricultural Sciences in China, 8(5), 597-604.

Mansour, A., \& El-Sharkawy, R. (2014). Simmondsin as natural alternative fungicide in squash root rot disease. Journal of Pest Management, 3143.

Menzies, J., \& Jarvis, W. (1994). The infestation of tomato seed by Fusarium oxysporum f. sp. radicis-lycopersici. Plant pathology, 43(2), 378-386.

Moosa, A., Sahi, S. T., Haq, I.-U.-., Farzand, A., Khan, S. A., \& Javaid, K. (2017). Antagonistic potential of Trichoderma isolates and manures against Fusarium wilt of tomato. International journal of vegetable science, 23(3), 207-218.

Morales, R. (2002). The history, botany and taxonomy of the genus Thymus. Thyme: the genus Thymus, 1, 1-43.

Mukta, J. A., Rahman, M., Sabir, A. A., Gupta, D. R., Surovy, M. Z., Rahman, M., \& Islam, M. T. (2017). Chitosan and plant probiotics application enhance growth and yield of strawberry. Biocatalysis and agricultural biotechnology, 11, 9-18.

Nimir, M., \& Ali-Dinar, H. (1989). Jojoba, a new cash crop in marginal lands. Paper presented at the I International Symposium on Horticultural Economics in Developing Countries 270.

Ostrowska, A., Gawliński, S., \& Szczubiałka, Z. (1991). Methods of analysis and assessment of soil and plant properties. A Catalgoue. Publisher: Institute of Environmental Protection-National Research Institute, Warsaw, 334.

Particka, C. A., \& Hancock, J. F. (2005). Field evaluation of strawberry genotypes for tolerance to black root rot on fumigated and nonfumigated soil. Journal of the American Society for Horticultural Science, 130(5), 688-693.

Redda, E. T., Ma, J., Mei, J., Li, M., Wu, B., \& Jiang, X. (2018). Antagonistic potential of different isolates of Trichoderma against Fusarium oxysporum, Rhizoctonia solani, and Botrytis cinerea. European Journal of Biology, 8(2), 12.

Ruiz-Romero, P., Valdez-Salas, B., González-Mendoza, D., \& MendezTrujillo, V. (2018). Antifungal effects of silver phytonanoparticles from Yucca shilerifera against strawberry soil-borne pathogens: Fusarium solani and Macrophomina phaseolina. Mycobiology, 46(1), 47-51.

Schleifer, K.-H. (2009). Phylum XIII. Firmicutes Gibbons and Murray 1978, 5 (Firmacutes [sic] Gibbons and Murray 1978, 5) Bergey's Manual® of Systematic Bacteriology (pp. 19-1317): Springer.

Sinha, A., Harshita, D., Singh, R., \& Verma, A. (2018). Bioefficacy of Trichoderma harzianum and Trichoderma viride against Fusarium 
oxysporum f. sp. capsici causing wilt disease in chilli. Journal of Phytochemistry, 7(5), 965-966.

Suleiman, S. A., Gambo, S., \& Sunusi, M. (2019). AN IN VITRO ANTAGONISTIC EFFECT OF Trichoderma spp. AGAINST Fusarium oxysporum f. sp. lycopersici. JOURNAL OF SCIENCES-ISSN: 26161370, 3(1), 369-374.

Zargar, A., Bailey, C. B., Haushalter, R. W., Eiben, C. B., Katz, L., \& Keasling, J. D. (2017). Leveraging microbial biosynthetic pathways for the generation of 'drop-in'biofuels. Current opinion in biotechnology, 45, 156-163.

Zarzuelo, A., \& Crespo, E. (2002). The medicinal and non-medicinal uses of thyme. Thyme: the genus Thymus, 263-292.

$$
\text { الملخص العربي }
$$

تأثير الثيتوزان والتريكودرما وزيت الزعتر ومستخلص الجوجويا ضد مرض الذبول

\section{الفيوزارمي للفراولة}

$$
\begin{aligned}
& \text { مجدي عبد الظاهر مسعود * أحمد محمد كردي * أحمد عبد الفتاح عبد المجيا } \\
& \text { أحمد إبراهيم عبد الباري حفلث ** محمود محمد سحير* } \\
& \text { *قسم وقاية النبات كلية الزراعة (سابا باشا) جامعة الإسكندرية } \\
& \text { ** قسم النبات الزراعي كلية الزراعة (سابا باشا) جامعة الإسكندرية }
\end{aligned}
$$

تأثثر الثيتوزان والتريكودرما وزيت الزعنر ومستخلص الجوجوبا ضد مرض الذبول الفيوزارمي على محصول الفراولة

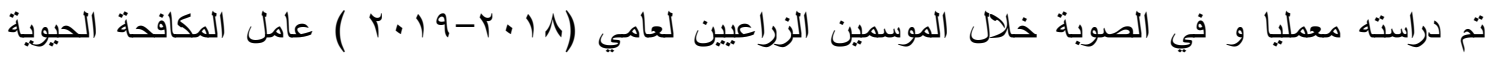
(التريكودرما هرزيانم) تم عزله في معمل كلية الزراعة سابا باشا جامعة الإسكندرية ، مصر • في الاختبار المعلي تم تقدير تأثير المعاملات الحيوية على نمو الفطر الممرض. في تجربة الصوبة تم إضافة المعاملات بثلاث طرق إضافة : الرش و حقن التربة و خليط بين الطريقتنن. في التجربة المعملية المعاملات ( الثيتوزان عند تركيز ع جم / لتز يليه التريكودرما ثم مركب التوب برفكت عند تركيز ع مل / لتز) قامت بتنتيط نمو الفطر الممرض


أن الخلط بين طريقتن الإضافة (الرش الورقي والحقن في التربة) لها دور مهم في مكافحة مرض الذبول الفيوزارمي ، بالإضافة إلى أن زيت الزعتر اعطى اقل فاعلية في مكافحة المسبب المرضي ـ اعلى تقدير للكلوروفيل كان



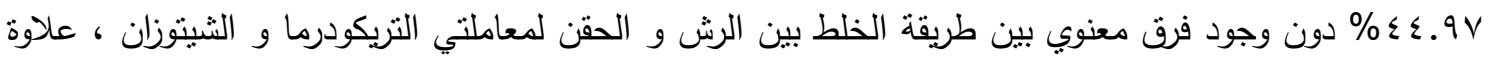
على ذلك المعاملة بالثبيتوزان و التريكودرما و التوب بيرفكت اظهرت زيادة معناويه في الوزن الجاف و الوزن الرطب لنباتات الفراولة و أقل نسبة إصابة و أقل شدة إصابة بالمرض ، كذلك أظهرت هذه المعاملات أعلى طول 
